Reprod. Nutr. Dévelop., 1987, 27 (6), 1005-1012.

\title{
Studies on the effect of bile and lipolysis products on pancreatic lipase and colipase activity in vitro
}

\author{
Monique MARTIGNE, R. JULIEN, L. SARDA (') \\ Laboratoire de Biochimie, Faculté des Sciences Saint-Charles, \\ Place V. Hugo, 13331 Marseille Cedex 3, France.
}

Summary. This study shows that human bile, at a concentration in the range of that found in the intestinal lumen, inhibited the hydrolysis of emulsified triolein by pancreatic lipase in vitro. The addition of colipase in excess to lipase failed to restore lipolytic activity. In contrast, a partially degraded emulsion of triolein containing diacylglycerol, monoacylglycerol and free fatty acid was hydrolysed by lipase and colipase in the presence of bile. The results presented in this paper allow to conclude that triacylglycerol digestive products associated with emulsified lipid played an important role in the intraluminal degradation of dietary fat by pancreatic lipase and colipase in the presence of bile.

\section{Introduction.}

In vitro hydrolysis of water-soluble long or short-chain triacylglycerols, such as triolein or tributyrin, by pancreatic lipase is inhibited by various active surface agents, including bile salts (Semeriva and Desnuelle, 1979; Borgstrom et al., 1979a), phospholipids (Borgstrom, 1980 ; Patton and Carey, 1981 ; Carey, 1983), ionic and non-ionic detergents (Gargouri et al., 1983) and amphiphilic proteins (Borgstrom and Erlanson, 1978 ; Blackberg et al., 1979 ; Gargouri et al., 1984, 1985). It is well established that, under in vitro conditions, the hydrolysis of triacylglycerol by pancreatic lipase is inhibited by naturally occuring bile salts at a concentration near the critical micellar concentration. However, inhibition by bile salts in vitro is fully reversed by the addition of colipase, a protein found in the exocrine pancreas secretion of mammals and birds. Colipase not only restores pancreatic lipase activity but also prevents the enzyme from surface denaturation at lipid-water interface. Under optimal conditions, interfacial lipolysis proceeds at a maximal rate and follows zero-order kinetics during the first minutes of hydrolysis. Based on these observations, it was concluded that in vivo digestion of dietary fat by lipase and colipase was not impaired by the bile salts present in the intestinal lumen. Also, the rate of hydrolysis of short or long-chain triacylglycerol by pancreatic lipase was markedly decreased by the addition of

(1) To whom correspondence should be addressed. 
phosphatidylcholine to the assay system. The kinetics of triacylglycerol hydrolysis showed a long lag-period which was abolished by the addition of bile salts. Furthermore, the initial rate of the reaction was increased by adding colipase to the lipolytic system (Carey, 1983). In some studies, a commercial emulsion of soya oil stabilized with egg phosphatidylcholine and glycerol (Intralipid) has been used as a lipid substrate to assay pancreatic lipase activity in vitro (Borgstrom et al., 1979b). Hydrolysis of the Intralipid emulsion showed a similar lag-period that could be shortened either by increasing the colipase/lipase ratio well above its value in the pancreatic secretion, or by submitting the secretory form of colipase (procolipase) to limited proteolysis by trypsin (Borgstrom et al., 1979b). Finally, it was shown that after previous incubation of the Intralipid emulsion with pancreatic phospholipase $A_{2}$, triacylglycerol was hydrolysed by pancreatic lipase at a high rate. Free fatty acids released by the enzymatic degradation of phosphatidylcholine were shown to be the activators of the triacylglycerol hydrolysis by lipase and colipase. This was confirmed in further studies (Larsson and Erlanson-Albertsson, 1986) on the effect of fatty acids on the hydrolysis of Intralipid by lipase and colipase in the presence of mixed micelles of sodium taurodeoxycholate and phosphatidylcholine. Gargouri et al. (1986a, 1986b) have recently reported experimental evidence supporting the conclusion that gastric lipolysis might be of first importance for pancreatic lipase and colipase catalysed hydrolysis of dietary fat in vivo. Using Intralipid as substrate, they showed that lipolysis was dependent on preincubation of the substrate with human gastric juice or pure gastric lipase.

Since phospholipids found with bile salts in the intestinal lumen are mostly of hepatic origin (Carey, 1983), we thought it interesting to investigate the effect of bile on in vitro hydrolysis of long-chain triacylglycerol under conditions approaching those prevailing in the intestinal lumen. The assay were performed in the absence and the presence of colipase (procolipase or trypsin-treated) using, as a substrate, an emulsion of triolein containing no lipolytic product or previously submitted to partial hydrolysis by pancreatic lipase.

\section{Material and methods.}

Bile and bile salts. - Human vesicular bile was collected by puncture of the gallbladder. Bile samples which contained appreciable amounts of lysophosphatidylcholine were discarded. All samples of bile were centrifuged at $15000 \times \mathrm{g}$ for $20 \mathrm{~min}$ to remove mucoproteins and then stored at $4{ }^{\circ} \mathrm{C}$. The bile salt and phosphatidylcholine contents of the bile samples were determined according to the methods of Domingo et al. (1972) and Amic et al. (1972). The average concentrations of bile salts and phosphatidylcholine in the bile samples were $130 \mathrm{mM}$ and $35 \mathrm{mM}$, respectively.

A mixture of pure bile salts (Calbiochem) was prepared in distilled water in the same molar proportions as those found in human bile (Street et al., 1983; Burnett, 1965 ; Alvaro et al., 1986), as follows : taurocholate : 12, glycocholate : 30 , taurodeoxycholate : 8 , glycodeoxycholate : 12 , taurochenodeoxycholate : 13 , glycochenodeoxycholate : 25 . 
Lipase and colipase. - Lipase (Rathelot et al., 1981a) and colipase (Canioni et al., 1977) were prepared in the laboratory from horse and pig pancreas homogenate, respectively. As reported previously (Rathelot et al., 1981a), activation of pancreatic lipase by colipase shows no species specificity. Treatment of native colipase (procolipase) with trypsin was carried out as described previously (Rathelot et al., 1981b).

Determination of lipase activity. - Triolein (neutralized olive oil) was emulsified in gum arabic and used as a substrate for assaying lipase activity. Assay conditions were similar to standard assay conditions (Rathelot et al., 1975), except for colipase and bile salts or bile that were added in variable amounts to the reaction system. Lipase activity was also assayed using an equal amount of a partially hydrolysed emulsion of triolein obtained as follows : lipase (1 000 units) was added to $200 \mathrm{ml}$ of the gum arabic stabilized emulsion of triolein maintained at $20^{\circ} \mathrm{C}$. The $\mathrm{pH}$ of the reaction mixture was kept constant at 9 by the continuous titration of released fatty acids with $1 \mathrm{M} \mathrm{NaOH}$ until $10 \%$ of the total ester bonds of the lipid substrate were hydrolysed. Lipolysis was stopped by dropping the $\mathrm{pH}$ to 2 with $0.2 \mathrm{M} \mathrm{HCl}$. After $15 \mathrm{~min}$, the $\mathrm{pH}$ of the partially hydrolysed emulsion was raised to 9 with $0.2 \mathrm{M} \mathrm{NaOH}$. This emulsion was used within one day. Its final composition was calculated from the work of Constantin et al. (1960). This composition (moles \%) was: triacylglycerol: 58, diacylglycerol: 15, monoacylglycerol : 4, free fatty acid : 23 . Increasing volumes of human bile or pure bile salts were added to the lipolytic system previous to lipase. In all assays, the reaction was started by introducing the same amount of enzyme, which corresponded to 12 lipase units as measured under standard conditions (Rathelot et al., 1975). When colipase was present, it was added in five-fold molar excess of lipase. Under assay conditions, the kinetics of hydrolysis showed no lag-time, and activity was calculated from the initial slope of the kinetic curve. In all cases, activity was expressed in enzyme units. One lipase unit corresponded to the release of one microequivalent fatty acid per min under assay conditions.

\section{Results.}

The influence of increasing concentrations of human bile on the hydrolysis of triolein by pancreatic lipase was first studied in the absence of colipase. The results presented in figure 1 show the variation of the initial rate of the lipolytic reaction as a function of bile concentration expressed as total bile salts. The hydrolysis of pure triolein by lipase was inhibited by bile at bile salt concentrations of about 2 to $4 \mathrm{mM}$ (curve a). Inhibition by bile was comparable to that observed with equal amounts of pure bile salts (curve b). When a substrate emulsion containing triolein digestive products was used, hydrolysis by pancreatic lipase was very low. Almost no hydrolysis occurred upon the addition of increasing concentrations of bile (curve c) or bile salts (curve d) in the reaction system.

In a second series of experiments, lipase activity was determined in the presence of colipase (native or trypsin-treated). The results presented in figure 2 show that (curve a) the addition of colipase fully restored lipase activity against 


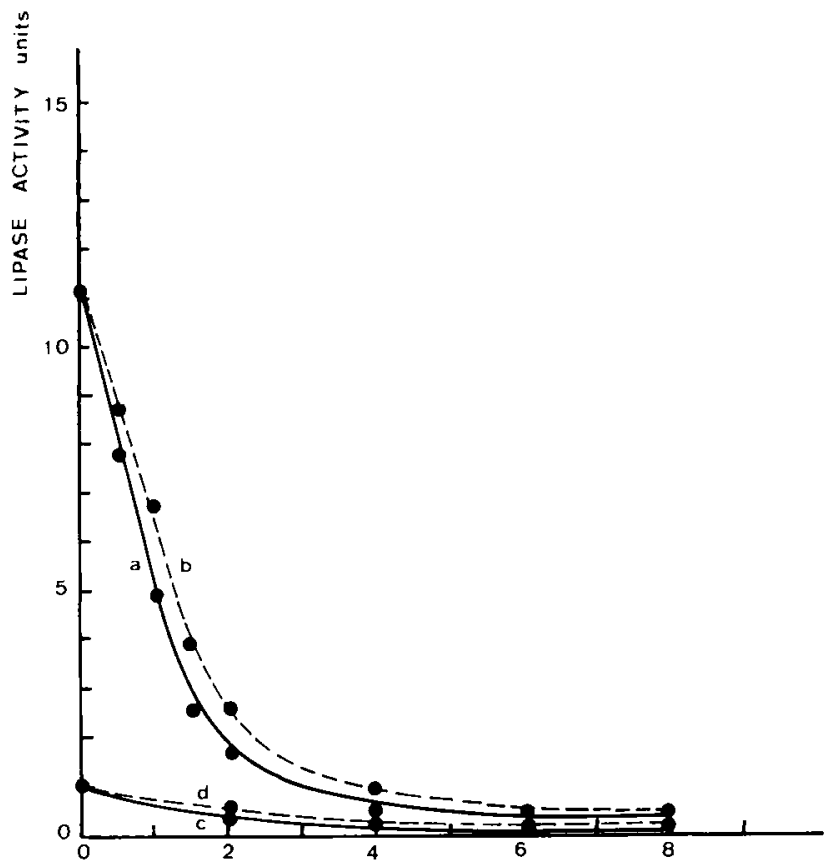

FIG. 1. - Effect of varying concentrations of bile and pure bile salts on the activity of pancreatic lipase on triolein in the absence of colipase. Activity was determined on pure triolein (curves a and b) and on prehydrolyzed triolein (curves $c$ and d). Solid lines: assays performed in the presence of bile. Dotted lines : assays performed in the presence of pure bile salts. The same amount of enzyme (12 lipase units) was used in all assays. Bile or bile salts were added to the lipid emulsion prior to lipase. Bile concentration is expressed as final bile salt concentration in the assay system. Similar results were obtained with native or trypsin-activated colipase.

pure triolein mixed with bile. This activating effect, however, was restricted to bile concentrations below 2 to $\mathrm{mM}$ bile salts. At higher concentrations, the rate of lipolysis remained very low. In no assays did lipolytic kinetics show a lag-time and no difference was observed between the presence of native and trypsin-treated colipase. Thus, the inhibitory effect of bile on the hydrolysis of pure triolein by lipase and colipase was stronger than that of pure bile salts at a concentration above 3 to $4 \mathrm{mM}$ (curve b). Curves $c$ and $d$ present results obtained under the same conditions but using a partially hydrolysed emulsion of triolein containing lipolytic products as the substrate for lipase and colipase. These curves show that the previous degradation of the long-chain triacylglycerol emulsion allowed further hydrolysis by lipase in the presence of its cofactor. The initial rate of the reaction was not different at bile salt concentrations as hight as $8 \mathrm{mM}$ in either the presence of bile or pure bile salts. The rate of lipolysis accounted for about $40 \%$ of that observed under conditions used for standard determination of lipase activity. In all experiments shown in figure 2, very similar results were obtained with native colipase or trypsin-treated cofactor. 


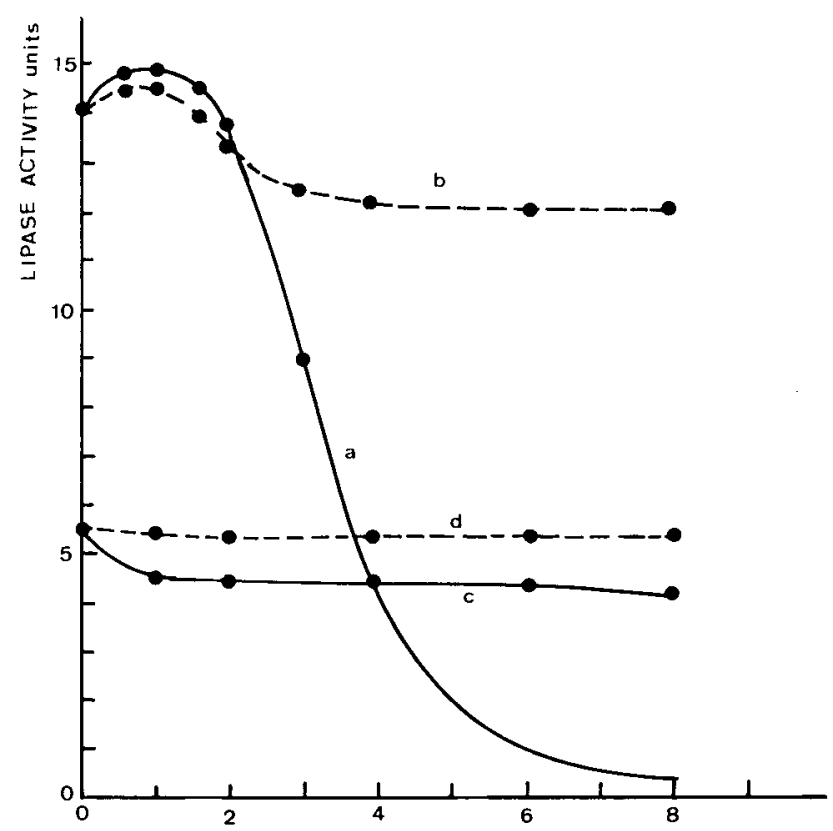

FIG. 2. - Effect of varying concentrations of bile or pure bile salts on the activity of pancreatic lipase on triolein in the presence of colipase. Conditions for the determination of lipase activity are identical to those of experiments reported in figure 1. Results are expressed as in figure 1. Similar results were obtained with equal amounts of native or trypsin activated colipase.

\section{Discussion.}

Fat digestion begins in the stomach where dietary triacylglycerols are partially hydrolysed to diacylglycerols and fatty acids by acid lipase (lingual and/or gastric). The whole conversion of triacylglycerols to monoacylglycerols and free fatty acids takes place further on in the intestinal lumen, in a highly complex lipid system resulting from the mixing of biliary lipids (bile salts, lecithin and cholesterol) and non-hydrolysed dietary triacyglycerol and phospholipid and the products of their enzyme degradation in the gastrointestinal tract. The lipase and colipase of pancreatic secretion are bound to the emulsified lipid phase which contains all the triacyglycerols and diacylglycerols and part of the monoacylglycerols, free fatty acids, biliary phospholipids and bile salts which are distributed between the emulsified lipid phase and the micellar phase in the intestinal lumen (Nalbone et al., 1974). Amphiphilic lipids concentrate at the surface of oil particles where lipolysis occurs.

Emulsions of pure short or long-chain triacylglycerols are mostly used to determine pancreatic lipase activity in vitro. By adding pure bile salts and colipase in large excess to lipase, conditions are obtained for the quantification of lipase activity under optimal conditions. However, such reaction systems may not be the best for characterizing the role of the lipase protein cofactor in the hydrolytic reaction at lipid-water interface under in vivo conditions. In view of a better 
characterization of the function, we studied the effect of colipase on pancreatic lipolysis in vitro under conditions approaching those encountered in the intestinal lumen during fat digestion. Lipolysis of triacylglycerol was studied in the absence and presence of triolein digestive products which resulted from the degradation of dietary fat.

Our results indicate that the hydrolysis of long-chain triacylglycerol (triolein) by pure pancreatic lipase was inhibited by bile and by the products of partial lipolysis in assays peiformed without adding colipase (fig. 1). Inhibition by human bile occurred at bile salt concentrations in the same range ( 2 to $4 \mathrm{mM}$ ), as in the case of pure bile salts. Inhibition of enzyme lipolysis was reversed by colipase. However, reactivation by colipase was very low in the presence of bile at bile salt concentrations above $3 \mathrm{mM}$. Under these conditions, the rate of hydrolysis of triolein by lipase and colipase accounted for less than $2 \%$ of that determined under the same conditions but with pure bile salts instead of bile in the assay system (fig. 2). The treatment of native colipase by trypsin had no effect on lipolysis under these conditions.

Lipase activity was then determined using a partially degraded emulsion of triolein in which $10 \%$ of the total ester bonds had been hydrolysed enzymatically. Pancreatic lipase showed little activity against this substrate both in the absence and the presence of bile or pure bile salts. Upon addition of colipase, activity was restored to $40 \%$ of that measured under optimal lipolytic conditions. In contrast to what was observed with pure triolein mixed with bile, lipase activity against this substrate remained constant when bile was added at bile salt concentrations as high as $8 \mathrm{mM}$ (fig. 2). This indicates that the presence of digestive products in the triolein emulsion determined the substantial hydrolysis by lipase and colipase in the presence of bile.

It is well established that pure lipase, free of colipase, is inactive on artificial or natural emulsions of pure triacylglycerols in the presence of amphiphiles such as bile salts or phospholipids due to enzyme desorption from the oil-water interface. Colipase activates lipolysis by enabling lipase to bind to its lipid substrate. Colipase adsorbs first to the lipid covered with amphiphile and serves as a specific anchor for pancreatic lipase. Alternatively, it has been proposed (Lairon et al., 1978) that, in the presence of bile, lipase and colipase first associate to biliary lipids to form a complex that subsequently binds to the emulsified substrate. Following this latter hypothesis, it is reasonable to suppose that the inhibition of lipolysis by bile was not due to competition between bile mixed micelles and oil particles for proteins of the enzyme system but, more probably, was due to a perturbation of the physical state of the triacylglycerol molecules by the amphiphilic constituants of bile adsorbed to interface. In this respect, it should be noted that biliary lecithin is in a different state compared to pure phosphatidylcholine since it is closely associated to bile salts, cholesterol and a polypeptide fraction in a stable lipoprotein complex (Nalbone et al., 1979). The state of biliary lecithin might explain the strong inhibitory effect of bile on lipase and colipase activity on triolein in vitro. This effect might be counteracted by triacylglycerol digestive products that would change the physical properties and organization of the lipid molecules at the surface of oil particles. Our experimental 
results provide further evidence (Hamosh, 1984 ; Gargouri et al., 1986a ; 1986b) that the partial hydrolysis of dietary fat occurring in the stomach is of prime importance for intraluminal lipolysis in vivo.

Reçu en avril 1987.

Accepté en juillet 1987.

Résumé. Etude de l'effet de la bile et des produits de la lipolyse sur l'activité de la lipase et de la colipase pancréatiques in vitro.

Cette étude montre que la bile humaine, en concentration de l'ordre de celle rencontrée dans la lumière intestinale, inhibe l'hydrolyse de la trioléine par la lipase pancréatique in vitro. L'addition de colipase en excès par rapport à la lipase, ne permet pas de restaurer l'activité lipolytique. Au contraire, une émulsion de trioléine partiellement dégradée, contenant des diglycérides, des monoglycérides et des acides gras libres est hydrolysée par la lipase et la colipase en présence de bile. Les résultats présentés dans cette communication montrent que les produits de la digestion des triglycérides associés à l'émulsion lipidique, jouent un rôle important dans la dégradation des graisses alimentaires par la lipase et la colipase en présence de bile.

\section{References}

ALVARO D., CANTAFORA A., ATTILI A., CORRADINI S. G., DE LUCA C., MINERVINI G., DI BIASE A., ANGELICO M., 1986. Relationships between bile salts hydrophilicity and phospholipid composition in bile of various animal species. Comp. Biochem. Physiol., 83 (B), $551-554$

AMIC J., LAIRON D., HAUTON J. C., 1972. Technique de dosage de I'orthophosphate de haute fiabilité. Clin. Chim. Acta, 40, 107-114.

BLACKBERG L., HERNELL O., BENGTSSON G., OLIVECRONA T., 1979. Colipase enhances hydrolysis of dietary triglycerides in the absence of bile salt. J. clin. Invest., 64, 1303-1308.

BORGSTROM B., 1980. Importance of phospholipids, phospholipase $A_{2}$ and fatty acids for the digestion of dietary fat. Gastroenterology, 78, 954-962.

BORGSTROM B., ERLANSON C., 1978. Interaction of serum albumin and other proteins with porcine pancreatic lipase. Gastroenterology, 75, 382-386.

BORGSTROM B., ERLANSON-ALBERTSSON C., WIELOCH T., 1979a, Pancreatic colipase : chemistry and physiology. J. Lipid Res., 20, 805-816.

BORGSTROM B., WIELOCH T., ERLANSON-ALBERTSSON, 1979b. Evidence for a pancreatic procolipase and its activation by trypsin. FEBS Lett., 108, 407-410.

BURNETT W., 1965. The pathogenesis of gall stones, 601-618. In TAYLOR W., The biliary system, Blackwell Sci. Publ., Oxford.

CANIONI P., JULIEN R., RATHELOT J., ROCHAT H. L., SARDA L., 1977. Characterization of Triton $\times 100$ extracted colipase from porcine pancreas. Biochimie, 59, 919-925.

CAREY M. C., 1983. Role of lecithin in the absorption of dietary fat, 33-63. In AVOGARO P., MANCINI M., RICCI G., PAOLETTI R., Phospholipids and atherosclerosis, Raven Press, New York.

CONSTANTIN M. J., PASERO L., DESNUELLE P., 1960. Quelques remarques complémentaires sur l'hydrolyse des triglycérides par la lipase pancréatique. Biochim. Biophys. Acta, 43, 103 109.

DOMINGO M., AMIC J., HAUTON J. C., 1972. Dosage automatique des sels biliaires conjugués de la bile par la 3-rr-hydroxystéroïde déshydrogénase. Clin. Chim. Acta, 37, 399-404

GARGOURI Y., JULIEN R., BOIS A. G., VERGER R., SARDA L., 1983. Studies on the detergent inhibition of pancreatic lipase activity. J. Lipid Res., 24, 1336-1342. 
GARGOURI Y., JULIEN R., SUGIHARA A., VERGER R., SARDA L., 1984. Inhibition of pancreatic and microbial lipases by proteins. Biochim. Biophys. Acta, 795, 326-331.

GARGOURI Y., PIERONI G., RIVIERE C., SUGIHARA A., SARDA L., VERGER R., 1985, Inhibition of lipases by proteins. A kinetic study with dicaprin monolayers. J. biol. Chem., 260, 22682273.

GARGOURI Y., PIERONI G., RIVIERE C., LOWE P. A., SAUNIERE J. F., SARDA L., VERGER R., 1986a. Importance of human gastric lipase for intestinal lipolysis: an in vitro study. Biochim. Biophys. Acta, 879, 419-423.

GARGOURI Y., PIERONI G., FERRATO F., RIVIERE C., SAUNIERE J. F., LOWE P. A., SARDA L., VERGER R., 1986b. Les lipases du tractus digestif. Reprod. Nutr. Dévelop., 26, 1163-1176.

HAMOSH M., 1984. Lingual lipase, 49-81. In BORGSTROM B., BROCKMAN H. L., Lipases, Elsevier, Amsterdam.

LAIRON D., NALBONE G., LAFONT H., LEONARDI J., DOMINGO N., HAUTON J. C., 1978. Possible roles of bile lipids and colipase in lipase adsorption. Biochemistry, 17, 5263-5269.

LARSSON A., ERLANSON-ALBERTSSON C., 1986. Effect of phosphatidylcholine and free fatty acids on the activity of pancreatic lipase-colipase. Biochim. Biophys. Acta, 876, 543-550.

NALBONE G., LAIRON D., LAFONT H., DOMINGO N., HAUTON J. C., SARDA L., 1974. Behaviour of biliary phospholipids during fat digestion. Lipids, 10, 765-770.

NALBONE G., LAFONT H., VIGNE J. L., DOMINGO N., LAIRON D., CHABERT C., LECHENE P., HAUTON J. C. 1979. The apoprotein fraction of the bile lipoprotein complex : isolation, partial characterization and phospholipid binding properties. Biochimie, 61, 1029-1041.

PATTON J. S., CAREY M. C., 1981. Inhibition of human pancreatic lipase-colipase activity by mixed bile salt-phospholipid micelles. Amer. J. Physiol., 241, G328-G336.

RATHELOT J., JULIEN R., BOSC-BIERNE I., GARGOURI Y., CANIONI P., SARDA L., 1981a. Horse bile salt and colipase on enzymatic lipolysis. Improved method for the determination of lipase and colipase. Biochimie, 57, 1117-1122.

RATHELOT J., JULIEN R., BOSC-BIERNE I., GARGOURI Y., CANIONI P., SARDA L., 1981a Horse pancreatic lipase. Interaction with colipase from various species. Biochimie, 63, 227-234.

RATHELOT J., CANIONI P., BOSC-BIERNE I., SARDA L., KAMOUN A., KAPTEIN R., COZZONE P. J. 1981b. Limited trypsinolysis of porcine and equine colipases. Spectroscopic and kinetic studies. Biochim. Biophys. Acta, 671, 155-163.

SEMERIVA M., DESNUELLE P., 1979. Pancreatic lipase and colipase. An example of heterogeneous biocatalysis, 319-370. In MEISTER A., Advances in enzymology, 48, Acad. Press, New York.

STREET J. M., TRAFFORD D. J. H., MAKIN H. L. J., 1983. The quantitative estimation of bile acids and their conjugates in human biological fluids. J. Lipid Res., 24, 491-511. 